\title{
Analysis of Energy Storage System Requirements for Aircraft Electric Taxiing Operations
}

\author{
Milos Lukic ${ }^{1}$, Paolo Giangrande ${ }^{1}$, Christian Klumpner ${ }^{1}$, Michael Galea ${ }^{2}$ \\ ${ }^{1}$ PEMC, University of Nottingham, Nottingham, United Kingdom \\ ${ }^{2}$ Key Laboratory of More Electric Aircraft Technology of Zhejiang Province, University of Nottingham Ningbo China \\ Milos.Lukic@nottingham.ac.uk
}

\begin{abstract}
This paper focuses on evaluating the energy and power requirements of a specific aircraft on-board electric taxiing (ET) system. The developed model of the investigated system is used to determine the requisites for a typical taxiing profile mission of a Boeing 737-400. Besides the derivation of the specifications, the comparison of batteries and electrochemical capacitors is outlined in the light of viable candidates for a local energy storage system (LESS). It is estimated that LESS should be sized for capacity of $19 \mathrm{kWh}$ and peak power of $81 \mathrm{~kW}$. The paper is concluded with a comparison and discussion on LESS topologies.
\end{abstract}

Keywords-Electric taxiing, Modelling, Energy Storage, Batteries, Supercapacitors.

\section{INTRODUCTION}

The commercial aviation industry has been moving towards adopting economically and environmentally sustainable models of aircraft, since many years ago. All aircraft operations that burn fuel are targeted for improvement and aircraft taxiing is among them. Indeed, means of taxiing that avoid engaging the main engines have been recently investigated for bringing down the fuel consumption.

One of the many proposed measures to alleviate the problems as mentioned above is the implementation of the on-board ET systems [1]. This solution is based on the concept of the powered wheel, in which electric traction motors are used to drive the aircraft during taxiing operation, [2]. Studies have shown that employment of these systems can reduce taxiing time by 9 minutes and total fuel burn by 4\% [3], [4]. Two possible configurations exist depending on whether the motor is installed in the nose landing gear (NLG) or the main landing gear (MLG). However, the preferable configuration is MLG one due to the higher traction effort available and the possibility of installing more than two traction motors [5].

ET systems are generally designed to provide a desirable kinematic performance such as maximum speed, maximum acceleration, and sufficient traction effort for breakaway events. For instance, requirements of Electric Green Taxiing System, a joint venture between Safran and Honeywell, are as follows: 1.) acceleration from standstill to 18 knots $(9.26 \mathrm{~m} / \mathrm{s})$ in $90 \mathrm{~s}, 2$.) acceleration from standstill to 10 knots $(5.14 \mathrm{~m} / \mathrm{s})$ in $45 \mathrm{~s}$ for active runway crossing, and 3.) high torque at zero speed in order to breakaway the aircraft from standstill [6].

As in any electric transportation application, choice of the

This work is funded by the INNOVATIVE doctoral programme. The INNOVATIVE programme is partially funded by the Marie Curie Initia Training Networks (ITN) action (project number 665468) and partially by the Institute for Aerospace Technology (IAT) at the University of Nottingham. electric energy source/s is an essential and critical aspect. In aircraft, electrical energy during taxiing can be provided either by the main engine integrated drive generators (IDGs) or through the auxiliary power unit (APU) generator. Nevertheless, IDGs cannot be used for powering the ET drive unit/s, since they are turned off during ET operations. At the moment, all available ET systems are powered from the APU generator, which features a rated power of $90 \mathrm{kVA}$ in case of a narrow-body aircraft [7]. By adopting this method, no modifications of the APU are required; however, it is not an optimal choice in terms of power capability and greenhouse gas emissions [8]. With both engines off, APU should not only be able to provide power for the ET system and other electrical loads that are typically powered by the IDGs, but also to produce bleed air for the environmental control system (ECS) and engine start-up. Therefore, the ET kinematic performance might be compromised when the APU operates at its critical working point (all electric loads, bleed air for ECS and start-up) [9]. To overcome the issue, the APU could be replaced by a more powerful one or a LESS could be installed for assisting the APU during the aircraft acceleration. The latter option allows the possibility of recovering energy during braking while also performing carbon-free taxiing operations.

This paper investigates the LESS requirements for achieving effective ET operations and it evaluates several LESS topologies considering an available ET drive unit as study case [10]. Accounting for aircraft specifications and road load dynamics, the ET system model is developed and discussed in Section II. In Section III, a typical taxiing mission profile is simulated assuming benchmark aircraft Boeing 737-400. The obtained results along with the requisite power and the energy profiles are then used to outline the LESS requirements. Finally, the energy storage devices suitable for the study case at hand are reviewed in Section IV, and in accordance with the needed demands, the potential LESS topologies are examined and compared in Section V.

\section{DESCRIPTION AND MODELLING OF THE ET SYSTEM}

The presented investigation is based on a direct drive ET system that employs a single traction motor per MLG. The selected motor is a 36 slots $/ 42$ poles synchronous permanent magnet machine (PMSM) featuring: 1.) outer rotor, 2.) $2 \times 3-$ phase fractional slot concentrated windings arrangement with $30^{\circ}$ displacement angle [11], and 3.) Halbach array configuration employing high-temperature resistant Samarium-Cobalt permanent magnets $\left(\psi_{\mathrm{pm}}=0.654 \mathrm{~Wb}\right)$. These design choices enhance the PMSM maximum torque allowing $7 \mathrm{kNm}$ at zero speed. Since two ET drive units are installed (i.e., one per MLG), an overall torque of $14 \mathrm{kNm}$ is generated for moving the B737-400 from a standstill. Each star of the machine 
is fed by the off-the-shelf 2-level 3-phase voltage source inverter (VSI) which are connected to the same DC link of 540V. The diagram of the ET drive unit for one MLG is shown in Fig. 1.

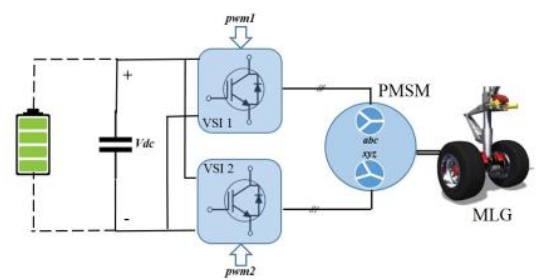

Fig.1: Schematic of the ET drive unit for a single MLG.

The model of the entire system is built using a forwardfacing method due to the natural possibility of implementing dynamic models [12]. Accordingly, the model input consists in the desired driving cycle (i.e., taxiing speed profile), which is fed to the pilot block (i.e., speed PI controller) along with the actual speed, as reported in Fig. 2. The output of the pilot represents a reference torque $\left(\mathrm{T}_{\mathrm{em}}^{*}\right)$ that has to be provided by the ET drive unit to the wheels so as to achieve desired kinematic performance. Based on the torque reference, the inverter and machine controller outputs the appropriate modulation indexes for both VSIs $\left(\mathrm{m}_{\mathrm{abc}, \mathrm{xyz}}^{*}\right)$ that are used to determine the real torque at the PMSM shaft. Finally, considering the dynamics of the aircraft, the actual speed is obtained and used as a feedback signal to the pilot block.

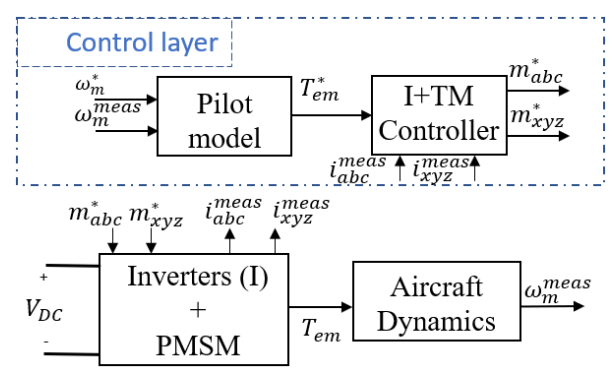

Fig. 2. Model and control architecture of the ET system.

\section{A. Machine and power converter models}

Machine's equations in the conventional $a b c(x y z)$ domain can be presented in matrix form as

$$
\mathbf{v}=\mathbf{R i}+\frac{\mathrm{d} \psi}{\mathrm{dt}}
$$

where variables $\mathbf{v}, \mathbf{i}$, and $\boldsymbol{\psi}$ represent the stator voltage, current, and flux linkage vectors respectively, in the form $\mathbf{f}=$ $\left[f_{a} f_{b} f_{c} f_{x} f_{y} f_{z}\right]^{T}$. $R$ corresponds to the stator resistance matrix, which is diagonal $\mathbf{R}=\operatorname{diag}\left(\mathrm{R}_{\mathrm{s}}\right)_{6 \times 6}$. By neglecting the saturation, the stator flux linkage can be expressed as the sum between permanent magnets (PMs) and currents-produced fluxes

$$
\boldsymbol{\psi}=\mathbf{L i}+\boldsymbol{\psi}_{\mathrm{pm}}
$$

where $\boldsymbol{\psi}_{\mathrm{pm}}$ has the same format as $\mathbf{f}$. The inductance matrix $\mathbf{L}$ accounts for the magnetic coupling among all phases and it is defined as:

$$
\mathbf{L}=\left[\begin{array}{ll}
\mathbf{L}_{\mathrm{s} 1, \mathrm{abc}} & \mathbf{M}_{\mathrm{s} 1, \mathrm{~s} 2} \\
\mathbf{M}_{\mathrm{s} 2, \mathrm{~s} 1} & \mathbf{L}_{\mathrm{s} 2, \mathrm{xyz}}
\end{array}\right]
$$

where $\mathbf{L}_{\mathrm{s} 1, \mathrm{abc}}$ and $\mathbf{L}_{\mathrm{s} 2, \mathrm{xyz}}$ represent the magnetic coupling among phases of the same star, whereas $\mathbf{M}_{\mathrm{s} 2, \mathrm{~s} 1}$ and $\mathbf{M}_{\mathrm{s} 1, \mathrm{~s} 2}$ are the mutual coupling terms between the two stars. $\mathbf{L}, \mathbf{M}$, and $\mathbf{R}$ are obtained from the finite element analysis of the PMSM. Phase resistance is $R_{s}=0.154 \Omega$, while $\mathbf{L}$ and $\mathbf{M}$ matrices have the form presented in (4) and (5) where $\mathrm{L}_{\mathrm{s}}=3.95 \mathrm{mH}$ and $\mathrm{M}_{\mathrm{s}}=1.031 \mathrm{mH}$.

$$
\begin{gathered}
\mathbf{L}_{\mathrm{s} 1, \mathrm{abc}}=\mathbf{L}_{\mathrm{s} 2, \mathrm{xyz}}=\left[\begin{array}{ccc}
\mathrm{L}_{\mathrm{s}} & 0 & 0 \\
0 & \mathrm{~L}_{\mathrm{s}} & 0 \\
0 & 0 & \mathrm{~L}_{\mathrm{s}}
\end{array}\right] \\
\mathbf{M}_{\mathrm{s} 1, \mathrm{~s} 2}=\mathbf{M}_{\mathrm{s} 2, \mathrm{~s} 1}^{\mathrm{T}}=\left[\begin{array}{ccc}
\mathrm{M}_{\mathrm{s}} & 0 & -\mathrm{M}_{\mathrm{s}} \\
-\mathrm{M}_{\mathrm{s}} & \mathrm{M}_{\mathrm{s}} & 0 \\
0 & -\mathrm{M}_{\mathrm{s}} & \mathrm{M}_{\mathrm{s}}
\end{array}\right]
\end{gathered}
$$

As for the conventional PMSM, the resulting $a b c(x y z)$ model is transferred into the $d q$ reference frame for exploiting the benefits of the rotating reference frame. Since the machine is powered from the two independent 3-phase VSIs, it can be treated as two single 3-phase PMSMs [13], [14]. Parameters of the $d q$ model are then found by applying two Park transformation matrices $(\mathrm{T}(\theta))$ to the machine's equation with $30^{\circ}$ degrees displaced angles $\left(\mathrm{T}(\theta)\right.$ and $\left.\mathrm{T}\left(\theta+30^{\circ}\right)\right)$ [15]. After the transformations are applied to the equations (1)-(3), the $d q$ model is obtained and its dynamic equations are shown in (6), while their graphical representation is depicted in Fig. 3. As expected $\mathrm{R}_{\mathrm{q}}=\mathrm{R}_{\mathrm{d}}=\mathrm{R}=\mathrm{R}_{\mathrm{s}}$ and it can be noticed that there is no coupling between $d$ and $q$ axes, which is the result of the specific PMSM construction and winding arrangement. Moreover, self $d$ and $q$ inductances are equal $\mathrm{L}_{\mathrm{q}}=\mathrm{L}_{\mathrm{d}}=\mathrm{L}=\mathrm{L}_{\mathrm{s}}$ as well as mutual inductances $\mathrm{M}_{\mathrm{q}}=\mathrm{M}_{\mathrm{d}}=\mathrm{M}=1.78 \mathrm{mH}$.

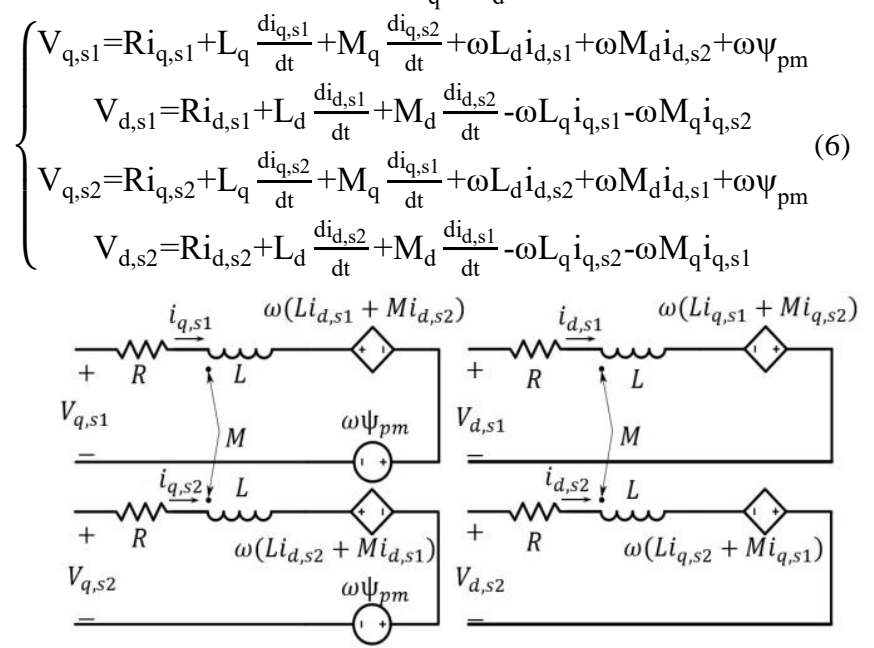

Fig. 3. Dynamic model of the $2 \times 3$-phase PMSM in the $d q$ reference frame.

Electromagnetic torque is calculated as the sum of two torque terms, each developed by one star. Since $\mathrm{L}_{\mathrm{q}}=\mathrm{L}_{\mathrm{d}}$ (i.e., the reluctance torque is null), the total torque is only dependent on the $q$ component currents, $\mathrm{i}_{\mathrm{q}, \mathrm{s} 1}$ and $\mathrm{i}_{\mathrm{q}, \mathrm{s} 2}$ [14].

$$
\mathrm{T}_{\mathrm{em}}=\frac{3}{2} \mathrm{p} \psi_{\mathrm{pm}}\left(\mathrm{i}_{\mathrm{q}, \mathrm{s} 1}+\mathrm{i}_{\mathrm{q}, \mathrm{s} 2}\right)
$$

Both inverters are also modelled in the $d q$ reference frame using procedure explained in [16]. Initially, the classic switching model is first averaged over the one switching period and afterwards the averaged model is transferred to the synchronous reference frame (Fig. 4). Similarly to the PMSM model, $d_{d, s 1}$ and $d_{q, s 1}$ are obtained applying $T(\theta)$ to the average 
phase duty cycles of star $1\left(\overline{\mathrm{S}_{\mathrm{abc}}}\right)$, while $\mathrm{d}_{\mathrm{d}, \mathrm{s} 2}$ and $\mathrm{d}_{\mathrm{q}, \mathrm{s} 2}$ are determined by applying $\mathrm{T}(\theta+30)$ to star $2\left(\overline{\mathrm{S}_{\mathrm{xyz}}}\right)$. The VSIs are controlled using a sine PWM modulation technique, thus $\overline{\mathrm{S}_{\mathrm{i}}}$ is calculated as $\frac{1}{2}\left(1+\mathrm{m}_{\mathrm{i}, \mathrm{ref}}\right)$. Finally, limitations to the machine model are imposed in terms of the maximum torque $(7 \mathrm{kNm})$ and power $(50 \mathrm{~kW})$.

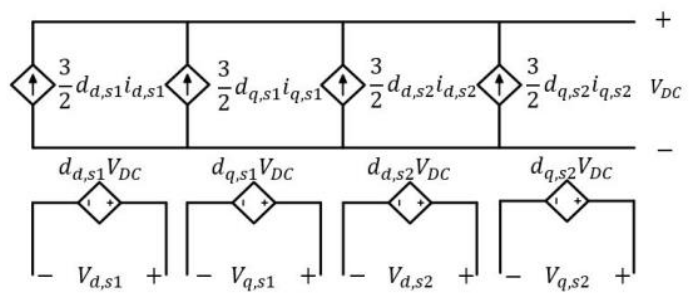

Fig. 4. Dynamic model of the inverters in the $d q$ reference frame.

\section{B. Aircraft model}

A simple two-dimensional longitudinal dynamic model can be used to represent the aircraft behaviour validly during ET. The traction force provided by the ET unit/s, $\mathrm{F}_{\text {traction }}$, should overcome the sum of all resistive forces that act on the aircraft, i.e., road load, intending to achieve demanded kinematic performance. The road load comprises rolling resistance, aerodynamic drag, and taxiway slope resistance. Hence, dynamic equations that describe the ground movement of the aircraft can be written as

$$
\begin{gathered}
\mathrm{m} \frac{\mathrm{dv}}{\mathrm{dt}}=\mathrm{F}_{\text {traction }}-\mathrm{F}_{\text {road }} \\
\mathrm{F}_{\text {road }}=\mathrm{c}_{\text {rr }} \mathrm{mg} \cos \alpha+\frac{1}{2} \rho_{\text {air }} \mathrm{c}_{\mathrm{v}} A v^{2}+\mathrm{mg} \sin \alpha
\end{gathered}
$$

where $c_{\mathrm{rr}}$ is the rolling resistance coefficient, $\mathrm{m}$ is the mass of the aircraft, $g$ is the gravitational constant $\left(9.81 \frac{\mathrm{m}}{\mathrm{s}^{2}}\right), \alpha$ is the angle of the taxiway slope, $\rho_{\text {air }}$ is the air density $\left(1.225 \frac{\mathrm{kg}}{\mathrm{m}^{3}}\right), \mathrm{c}_{\mathrm{v}}$ is the aerodynamic drag coefficient, $\mathrm{A}$ is the total wing area, and $\mathrm{v}$ is the aircraft's speed.

For convenience, (8) and (9) are rearranged in terms of the load torque and the total PMSM inertia [17]. Considering that the ET system under study utilises two electric motors, both road load force and reflected aircraft inertia are equally split between the two MLGs. Thus, the final equation describing the PMSM dynamics is

$$
\mathrm{J}_{\mathrm{t}} \frac{\mathrm{d} \omega_{\mathrm{m}}}{\mathrm{dt}}=\mathrm{T}_{\text {traction,mot }}-\frac{1}{2} \mathrm{rF}_{\text {road }}
$$

where $\omega_{\mathrm{m}}$ is the PMSM mechanical speed, $r$ is the radius of the MLG tyre, and $\mathrm{J}_{\mathrm{t}}$ is the total moment of inertia seen from the motor shaft. The latter one includes inertia of the motor $\left(\mathrm{J}_{\text {motor }}\right)$, wheel $\left(\mathrm{J}_{\text {wheel }}\right)$ and half of the reflected aircraft inertia $\left(\frac{1}{2} \mathrm{mr}^{2}\right)$ [18]. The aircraft parameters are presented in Table I.

TABLE I. SIMULATED AIRCRAFT (B737-400) MODEL PARAMETERS

\begin{tabular}{|c|c|c|c|c|c|}
\hline Parameter & $\mathrm{m}[\mathrm{t}]$ & $\mathrm{c}_{\mathrm{rr}}$ & ${\mathrm{A}\left[\mathrm{m}^{2}\right]}$ & $\mathrm{c}_{\mathrm{v}}$ & $\mathrm{r}[\mathrm{m}]$ \\
\hline Value & $69[19]$ & $0.09[20]$ & $\begin{array}{c}105.4 \\
{[19]}\end{array}$ & $\begin{array}{c}0.023 \\
{[21]}\end{array}$ & $\begin{array}{c}0.535 \\
{[19]}\end{array}$ \\
\hline
\end{tabular}

\section{ENERGY AND POWER REQUIREMENTS OF THE LESS}

The two most important requirements that LESS has to satisfy are 1.) sufficient amount of energy capacity so that full taxiing cycle can be guaranteed on one charge and 2.) high power capability to enable necessary acceleration and to maximise regeneration capability during braking. With the purpose of identifying those requirements, a typical taxiing driving cycle is analysed and fed to the developed ET system model. The mission profile is divided into two distinct taxiing operations, taxi-out (T-O) at Amsterdam Schiphol airport and taxi-in (T-I) at London Heathrow airport. Comparing with the other traction applications where many standard cycles already exist (e.g., UDDS for testing electric vehicles), standard taxiing profiles are still lacking for the ET application. Nevertheless, the cycles adopted in this work are a valuable reference point, since they are related to Europe's busiest and congested airports, where the ET implementation would be the most beneficial. The speed profiles are illustrated in Fig. 5 and Fig. 6 for both taxiout and taxi-in respectively.

The current at the DC link is used for determining the system input power, which is also given in Fig. 5 and Fig. 6. Total consumed energy can be obtained by numerical integration of the power at the DC link. The characteristics of the two taxiing profiles such as, maximum charging and discharging power
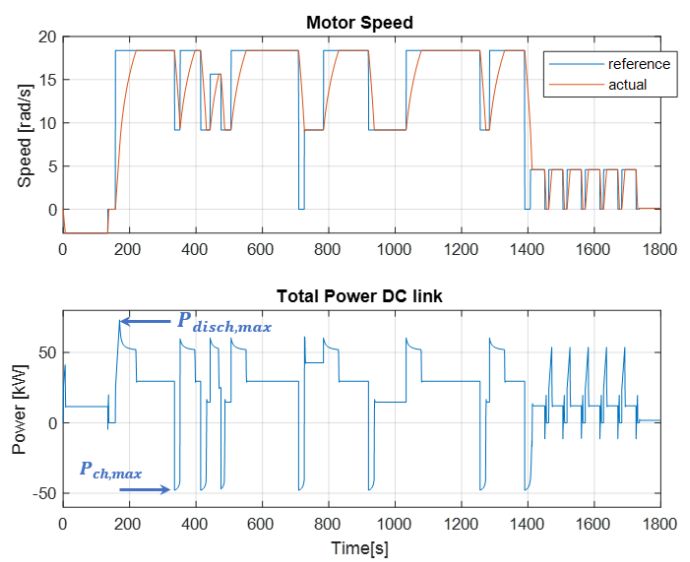

Fig. 5. Taxi-out speed profile and total power at the DC link.
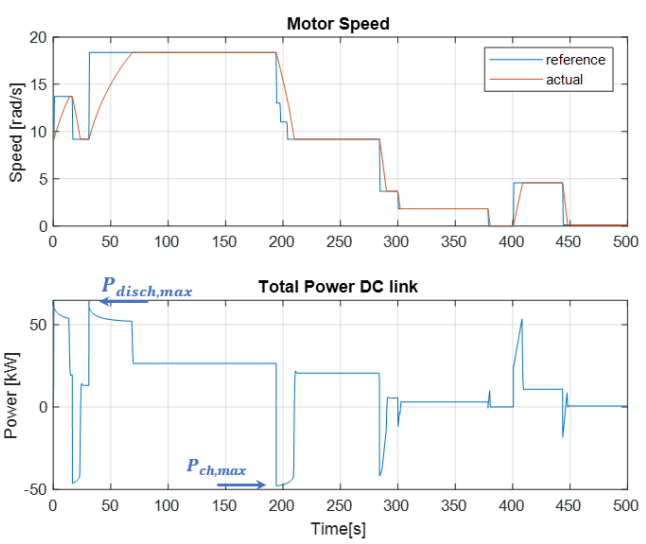

Fig. 6. Taxi-in speed profile and total power at the DC link. $\left(\mathrm{P}_{\text {ch,max }}\right.$ and $\left.\mathrm{P}_{\text {disch,max }}\right)$, average power $\left(\mathrm{P}_{\mathrm{avg}}\right)$, energy consumption $\left(\mathrm{E}_{\text {tot }}\right)$, maximum potential regenerated energy $\left(\mathrm{E}_{\text {reg }}\right)$ and its ratio $\left(\mathrm{r}=\frac{\mathrm{E}_{\text {reg }}}{\mathrm{E}_{\text {tot }}} 100 \%\right)$ are listed in Table II.

TABLE II. ENERGY CHARACTERISTICS OF THE TAXIING PROFILES

\begin{tabular}{|c|c|c|c|c|c|c|}
\hline & $\mathrm{P}_{\text {disch,max }}$ & $\left|\mathrm{P}_{\text {ch,max }}\right|$ & $\mathrm{P}_{\text {avg }}$ & $\mathrm{E}_{\text {tot }}$ & $\mathrm{E}_{\text {reg }}$ & $\mathrm{r}$ \\
\hline T-O & $73.2 \mathrm{~kW}$ & $51.2 \mathrm{~kW}$ & $22.7 \mathrm{~kW}$ & $11.3 \mathrm{kWh}$ & $1.5 \mathrm{kWh}$ & $13.2 \%$ \\
\hline T-I & $64.8 \mathrm{~kW}$ & $48 \mathrm{~kW}$ & $15.1 \mathrm{~kW}$ & $2.1 \mathrm{kWh}$ & $0.35 \mathrm{kWh}$ & $16.7 \%$ \\
\hline
\end{tabular}


As expected, the energy and power requirements are more stringent for taxi-out, since it is typically longer and the aircraft is heavier due to more fuel it carries at the beginning of the flight mission. Hence, the taxi-out is the most energy demanding stage and moreover high power demanding events are also foreseeable, e.g., accelerations from zero to maximum speed. During taxi-in, the aircraft already has initial taxiing speed, so high accelerations are unlikely to occur. However, due to the initial speed, braking is used more frequently which can be seen from the percentage of the possible regenerated energy, but since the cycle is shorter absolute value is still lower than for taxi-out.

Therefore, the LESS should have enough energy capacity to provide full taxi-in and taxi-out cycle on one charge and to be able to deliver maximum power for acceleration events. This leads to the required total energy of $13.5 \mathrm{kWh}$ and a maximum power of $73 \mathrm{~kW}$. Considering the maximum depth of discharge of $80 \%$ and efficiency of $90 \%$, the LESS should be sized for $18.7 \mathrm{kWh}$ energy capacity and discharge power of $81.1 \mathrm{~kW}$. Thus, ideally, the LESS for ET operations should have power to energy ratio $(\mathrm{P} / \mathrm{E})$ equal or close to 4.34 , in order to do not be oversized regarding energy nor regarding the power [22]. Besides the power and energy requirements, the LESS should be completely charged between two flights, i.e., during aircraft turnaround time. Typical turnaround time is 45 minutes, which means that continuous charge rates should be at least between $1 \mathrm{C}$ and $2 \mathrm{C}$. Another important aspect is the lifetime. Considering that one B737 makes 3 flight rotations per day, i.e., six taxiing missions per day, the LESS should be designed to have long lifetime, granting approximately 2000 missions per year. Thus, the LESS should be able to withstand high power stresses acting on it without compromising its lifetime. In the following sections, the potential devices and their configurations are addressed as possible candidates of the LESS for the ET application.

\section{ENERgy StORAGE DEVICES OVERVIEW}

It is widely recognised that electrochemical energy storage is the only suitable for aircraft use. In the following, batteries and electrochemical capacitors (EC), also known as supercapacitors (SC) or ultra-capacitors, will briefly be introduced along with their advantages and disadvantages.

\section{A. Batteries}

Batteries are electrochemical devices that convert potential chemical energy into electrical one during discharging and contrariwise in charge mode. This is possible due to the charge and mass transfer occurring in redox reactions, a type of faradaic process. Many different battery chemistries are available, most famous being: lead-acid, Ni-MH, and Li-ion. Generally speaking, Li-ion batteries are dominating the traction application and for this reason, they will be considered in the present work. Several diverse types of $\mathrm{Li}$-ion cells exist depending on the material used at the positive electrode (negative electrode is usually graphite). The most popular materials are $\mathrm{LiCoO}$ (LCO) and its congeners $\mathrm{Li}\left(\mathrm{Ni}_{\mathrm{x}} \mathrm{Mn}_{\mathrm{y}} \mathrm{Co}_{\mathrm{z}}\right) \mathrm{O}_{2}(\mathrm{NMC})$ and $\mathrm{Li}\left(\mathrm{Ni}_{1-\mathrm{x}-}\right.$ $\left.{ }_{\mathrm{y}} \mathrm{Co}_{\mathrm{x}} \mathrm{Al}_{\mathrm{y}}\right) \mathrm{O}_{2}$ (NCA) that all have layered structure, $\mathrm{Li}_{\mathrm{x}} \mathrm{MnO}_{4}$ (LMO) with spinel structure and $\mathrm{LiFePO}_{4}$ (LFP) with olivine. It is difficult to generalise among them since characteristics depend on the amount of active material used. For instance, a cell with the same chemistry from the same manufacturer can be optimised as a high energy (HE) cell or a high power (HP) cell depending on the thickness of the electrode material. However, general differences are given in Table III [23].

In traction applications, acceleration and decelerations are events that happen frequently and ET application is not an exception. During those events, the required power is usually much higher than the average power over the drive cycle. According to their specific power, batteries are not devices capable of providing high power (unless they are oversized). Therefore, the optimum LESS should have high power density and high energy density. ECs are devices with high power density, and they can be used in combination with batteries to absorb/deliver the power bursts during braking/acceleration.

TABLE III. CHARACTERISTICS OF TYPICAL LI-ION CELL CHEMISTRIES

\begin{tabular}{|c|c|c|c|c|c|}
\hline Feature & LCO & NMC & NCA & LMO & LFP \\
\hline $\mathrm{V}_{\max }[\mathrm{V}]$ & 4.2 & 4.1 & 4.2 & 4.2 & 3.6 \\
\hline $\mathrm{V}_{\text {nom }}[\mathrm{V}]$ & 3.7 & 3.7 & 3.7 & 3.7 & 3.4 \\
\hline$e[\mathrm{Wh} / \mathrm{kg}]$ & $90-180$ & $140-190$ & $220-240$ & $100-150$ & $80-140$ \\
\hline$p[\mathrm{~kW} / \mathrm{kg}]$ & $\sim 600$ & $500-3 \mathrm{e} 3$ & $1.5-1.9 \mathrm{e} 3$ & $\sim 1.8 \mathrm{e} 3$ & $\sim 2.5 \mathrm{e} 3$ \\
\hline
\end{tabular}

\section{B. Electrochemical Capacitors}

ECs, like any other capacitors, are devices that store energy by charge separation in the form of an electrostatic field. Albeit similar to the conventional electrolytic and dielectric capacitors, ECs differ in certain key aspects such as very high capacitance. This feature is obtained by utilizing porous materials as an electrode material, which guarantee high electrode surface area, and relying on the phenomenon of the electrical double layer (EDL), that naturally has small distance between charge layers.

When compared to the batteries, the process happening inside ECs is physical in nature and it is non-faradaic, i.e., no charge transfer occurs. Consequently, this process is highly reversible opposed to the redox reactions occurring in batteries and thus ECs can be cycled more than half a million times. Additionally, since the charge release is not limited by kinetic rates of the chemical reactions, the ECs inherently exhibit higher power densities than batteries. However, they can store 3-30 times less energy than batteries. Finally, ECs exhibit high symmetric charge and discharge rates, which is not the case with batteries featuring meager charge rates. Differences are highlighted in Table IV [24], [25].

\section{EVAluATION OF LESS TOPOLOGIES}

In this section, three LESS configurations are analysed, discussed, and compared and they are as follows: 1.) battery-only, 2.) hybrid LESS (HLESS) and 3.) LESS with the addition of the APU.

\section{A. Battery-only configuration}

In the battery-only configuration, the battery should be able to satisfy alone the requirements derived in section III. A battery employing cells featuring ratio equal or higher to 4.34 would automatically satisfy the maximum power requirement, provided that battery is sized for energy capacity of the necessary $18.7 \mathrm{kWh}$ or more. Therefore, HE cells with $\mathrm{P} / \mathrm{E} \geq 4.34$ are naturally preferable due to their inheritably higher specific energy. On the other hand, HE cells have lower 
TABLE IV. COMPARISON BETWEEN BATTERIES AND ECS

\begin{tabular}{|c|c|c|}
\hline Property & Battery & $\begin{array}{c}\text { Electrochemical } \\
\text { capacitor }\end{array}$ \\
\hline Storage mechanism & $\begin{array}{c}\text { Chemical (redox } \\
\text { reaction) }\end{array}$ & $\begin{array}{c}\text { Physical (charge } \\
\text { separation) }\end{array}$ \\
\hline Power density & Low-Moderate & High \\
\hline Power limitation & $\begin{array}{c}\text { Reaction kinetics, } \\
\text { mass transport. }\end{array}$ & Electrolyte conductivity \\
\hline Energy density & High (bulk) & Limited (surface) \\
\hline Charge rate & $\begin{array}{c}\text { Kinetically limited } \\
\text { Charge: } 1-5 \mathrm{~h} \\
\text { Discharge: } 0.3-3 \mathrm{~h}\end{array}$ & $\begin{array}{c}\text { High } \\
\text { Discharge: } 0.3-30 \mathrm{sec}\end{array}$ \\
\hline Cycle life & Low & High \\
\hline Swelling & Yes & No \\
\hline $\begin{array}{c}\text { Temperature } \\
\text { operating range }\end{array}$ & $-20^{\circ} \mathrm{C}$ to $+40^{\circ} \mathrm{C}$ & $-40^{\circ} \mathrm{C}$ to $+65^{\circ} \mathrm{C}\left(+85^{\circ} \mathrm{C}\right)$ \\
\hline Efficiency & $0.85-0.95$ & $0.95-0.98$ \\
\hline
\end{tabular}

charging rates compared to HP ones [23]. Thus, more braking energy can be absorbed using HP batteries. Although specific energy densities of HP cells are lower relative to the ones of HE cells, that difference is slowly bridged. As a comparison, parameters of the HE and HP cells by Kokam are presented in Table V along with the A123 HP cell. Moreover, the mass of the battery is also shown, if those cells would be used for sizing the LESS by energy capacity.

TABLE V. CHARACTERISTICS OF THE HE AND HP CELLS FOR BATTERYONLY CONFIGURATION

\begin{tabular}{|c|c|c|c|}
\hline Parameter & Kokam HE & Kokam HP & A123 HP \\
\hline Product & SLPB75106205 & SLPB78205130H & ANR26650 \\
\hline Chemistry & NMC & NMC & LFP \\
\hline Volatge [V] & 3.7 & 3.7 & 3.3 \\
\hline Capacity [Ah] & 16 & 16 & 2.5 \\
\hline$e$ [Wh/kg] & 174.11 & 145.81 & 108.56 \\
\hline $\begin{array}{c}\text { Continous } \\
\text { discharge }\end{array}$ & $5 \mathrm{C}$ & $8 \mathrm{C}$ & $20 \mathrm{C}$ \\
\hline $\begin{array}{c}\text { Pulse } \\
\text { discharge }\end{array}$ & $8 \mathrm{C}$ & $15 \mathrm{C}$ & $48 \mathrm{C}$ \\
\hline \begin{tabular}{c}
$\mathrm{m}_{\text {battery }}[\mathrm{kg}]$ \\
\hline $\mathrm{P}_{\text {battery }}[\mathrm{kW}]$
\end{tabular} & 107.4 & 128.25 & 172.3 \\
\hline As expected & 93.5 & 149.6 & 374 \\
\hline
\end{tabular}

As expected, the maximum power requirement is automatically achieved using all three cells. However, the Kokam HP battery will result in a $20 \%$ increase of weight compared to the HE one whilst using the A123 cell increases the battery pack weight by $60 \%$ mainly due to the lower energy density caused by low LFP cell voltage. Assuming that the charge rate of the Kokam $\mathrm{HE}$ cell is equal to $1 \mathrm{C}$, actual regenerated energy amounts to $0.61 \mathrm{kWh}$, which is a $60 \%$ drop from $1.5 \mathrm{kWh}$ of the total possible recoverable energy during braking. In case of the HP Kokam battery, assuming $2 \mathrm{C}$ charge rate, the actual recovered energy is doubled compared to the $\mathrm{HE}$ battery, $1.2 \mathrm{kWh}$. Furthermore, according to the manufacturer's datasheets, some batteries can tolerate high regenerative pulses for approx. 10s. Thus, in practice, due to the typical braking profile more energy can potentially be regenerated. Even though using the HP cells appears advantageous, in aerospace applications weight represents one of the most important concerns. Thus, another option is to use the HE battery, to exploit the high energy density benefit, assisted by SCs due to their significantly higher and symmetrical power handling capability in a HLESS configuration. This arrangement not only reduces the stress on the HE battery and guarantees a long lifetime, but it further improves the regeneration capability.

\section{B. HLESS configuration}

In the case of HLESS, power sharing strategy determines the behavior of the whole LESS [26]. The most common is a rule-based strategy, which imposes the upper and lower power boundaries that battery can experience. Namely, limiting charge $\left(\mathrm{P}_{\text {ch,lim }}\right)$ and discharge $\left(\mathrm{P}_{\text {disch,lim }}\right)$ powers of the battery are defined. If demanded power $\left(\mathrm{P}_{\text {total }}\right)$ exceeds those limits, SC bank should provide the difference. This power sharing strategy is illustrated in Fig. 7 along with the battery power boundaries.

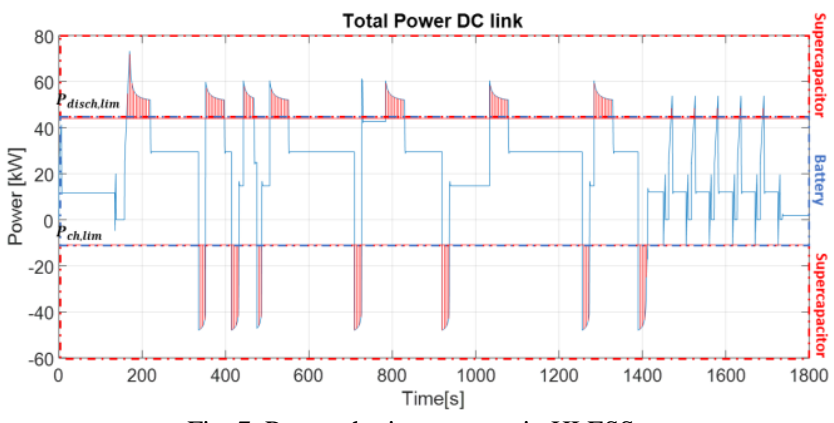

Fig. 7. Power sharing strategy in HLESS.

Once the SC power profile is defined, the difference between maximum and lowest SC energy (i.e., energy swing $\Delta \mathrm{E}_{\mathrm{SC}}$ ) can be calculated which is then used for sizing the $\mathrm{SC}$ bank. Usually, the battery lower power boundary $\mathrm{P}_{\mathrm{ch}, \mathrm{lim}}$ is set to zero meaning that the SC bank will absorb all regenerated energy sparing the battery from the high power charging stresses, or it is set to the maximum charging power that battery can experience. Many options were proposed for selecting the upper boundary $\mathrm{P}_{\text {disch,lim. }}$. For instance, in [27] it was shown that different $\mathrm{P}_{\text {disch,lim }}$ values yield different $\Delta \mathrm{E}_{\mathrm{SC}}$ and hence it was proposed to select the value that results in the minimum $\Delta \mathrm{E}_{\mathrm{SC}}$ (i.e., minimum SC size/weight). A Maxwell EDL SC cell BCAP 3000 with parameters stated in [28] is considered to be hybridized with the Kokam HE cell as an example.

The maximum charging power of the battery is limited to $\mathrm{P}_{\mathrm{ch}, \mathrm{lim}}=-11 \mathrm{~kW}$, while the maximum discharge power which gives minimum $\Delta \mathrm{E}_{\mathrm{SC}}$ is found to be $\mathrm{P}_{\text {disch,lim }}=44 \mathrm{~kW}$. Assuming a discharge ratio of 0.5 , the required SC stored energy sums to $293 \mathrm{Wh}$ resulting in $48.83 \mathrm{~kg}$ of SCs. Therefore, the total mass is slightly higher compared to the battery-only system with HP Kokam cells. Considering that the SC is usually connected to the DC link bus through a DC/DC power converter, its weight should also be included when assessing the total added weight to the system. However, the advantage of this configuration is that all regenerated energy can be saved while reducing stresses on the battery which will increase its lifetime [27]. 


\section{LESS and APU configuration}

If the future aircraft that are to be equipped with the ET system continue utilising conventional ECS, the APU should be operational in order to provide bleed air to it. Thus, another possible solution is to demand electric power from the APU, as it is available, but not as the primary power source. For instance, the APU generator could provide only half of the average power per ET unit (i.e., $23 \mathrm{~kW}$ in total), which is around $25 \%$ of its rated power. By adopting this strategy, the LESS weight would be reduced because half of the required energy would be supplied from the APU. Therefore, the P/E ratio of the LESS would almost double and be around 7.5 with the LESS's main task being to assist the APU during braking and acceleration events. These requirements are similar to the ones of the batteries used in series hybrid electric vehicles. In this scenario, the ET system is still dependent on the rest of the aircraft system, but the APU would be able to start the main engines without compromising the performance of the ET system. Also, APU emissions would be cut down since it would be operating far from its critical operation point.

\section{CONCLUSIONS}

In this paper, the requirements of the LESS for innovative aircraft ET application are presented. To assess the requirements, the model of the whole system that includes $2 \times 3$ phase PMSM, 2-level 3-phase VSIs, aircraft dynamics and road load, was developed and presented in Section II. Simulation of the B737-400 ET performance was run for two typical taxiing cycles at some of Europe's busiest airports. It was concluded that LESS should be designed to store at least 19kWh allowing peak discharge power of $81 \mathrm{~kW}$. Finally, batteries and ECs are introduced as viable energy storage devices and three possible LESS topologies were discussed. Using battery-only and HLESS configurations, the ET system would result in being completely autonomous and independent from the rest of the aircraft power system. Also, both options are gainful since they enable complete emission-free taxiing. Furthermore, in the case of HLESS, stresses on the battery could be minimized through an appropriate power sharing strategy. However, the control of this system is more complicated, and weight of additional installed converters should adequately be assessed. Finally, a LESS solution relying on the APU is proposed. Until ECSs that use electric energy are also introduced to the short-haul aircraft, the APU will still have to provide the bleed air for conventional ECS operation. In this scenario, a portion of the demanded ET power can still be supplied by the APU. Such solution leads to the lowest weight among the considered LESS configurations, but the taxing operation would not be emission-free.

\section{REFERENCES}

[1] F. Re, "Viability and state of the art of environmentally friendly aircraft taxiing systems," 2012 Electr. Syst. Aircraft, Railw. Sh. Propuls., pp. 1-6, 2012.

[2] J. Tao, J. Guo, and C. Liu, "A review of powered wheel for aircraft," 2016 IEEE Int. Conf. Aircr. Util. Syst., pp. 378-383, 2016.

[3] "WheelTug Webinar." [Online]. Available: http://media.wheeltug.com/. [Accessed: 06-Aug-2019].

[4] N. Dzikus, J. Fuchte, A. Lau, and V. Gollnick, "Potential for Fuel Reduction through Electric Taxiing," 11th AIAA Aviat. Technol. Integr. Oper. Conf., no. September, pp. 1-9, 2011.
[5] M. Lukic et al., "State of the Art of Electric Taxiing Systems," 2018 Int. Conf. Electr. Syst. Aircraft, Railw. Sh. Propuls. Road Veh. Int. Transp. Electrif. Conf., 2018.

[6] "EGTS." [Online]. Available: https://www.arts-etmetiers.asso.fr/manifestation_cr/678_compte_rendu.pdf [Accessed: 16 May - 2018]. [Accessed: 06-Aug-2019].

[7] V. Madonna, P. Giangrande, and M. Galea, "Electrical Power Generation in Aircraft: Review, Challenges, and Opportunities," IEEE Trans. Transp. Electrif., vol. 4, no. 3, pp. 646-659, 2018.

[8] Y. Nicolas, "eTaxi, taxiing aircraft with engines stopped." [Online]. Available: http://www.smartcockpit.com/docs/taxiing-aircraft-withengines-stopped.pdf. [Accessed: 06-Aug-2019].

[9] P. C. Roling, P. Sillekens, R. Curran, and W. D. Wilder, "The effects of Electric Taxi Systems on airport surface congestion," 15th AIAA Aviat. Technol. Integr. Oper. Conf., no. June, pp. 1-10, 2015.

[10]M. Galea, Z. Xu, C. Tighe, T. Hamiti, C. Gerada, and S. Pickering, "Development of an aircraft wheel actuator for green taxiing," Proc. - 2014 Int. Conf. Electr. Mach. ICEM 2014, pp. 2492-2498, 2014.

[11]P. Giangrande, V. Madonna, S. Nuzzo, and M. Galea, "Design of FaultTolerant Dual Three-Phase Winding PMSM for Helicopter Landing Gear EMA,” 2018 IEEE Int. Conf. Electr. Syst. Aircraft, Railw. Sh. Propuls. Road Veh. Int. Transp. Electrif. Conf., pp. 1-6, 2019.

[12]D. W. Gao, C. Mi, and A. Emadi, "Modeling and Simulation of Electric and Hybrid Vehicles," Proc. IEEE, vol. 95, no. 4, pp. 729-745, 2007.

[13] Y. Hu, Z. Q. Zhu, and M. Odavic, "Comparison of Two-Individual Current Control and Vector Space Decomposition Control for Dual Three-Phase PMSM,” IEEE Trans. Ind. Appl., vol. 53, no. 5, pp. 4483-4492, 2017.

[14]J. Karttunen et al., "Dual Three-Phase Permanent Magnet Synchronous Machine Supplied by Two Independent Voltage Source Inverters," in International Symposium on Power Electronics Power Electronics, Electrical Drives, Automation and Motion, 2012, pp. 741-747.

[15]A. Galassini et al., "Distributed Current Control for Multi-Three Phase Synchronous Machines in Fault Conditions," 2016 XXII Int. Conf. Electr. Mach., pp. 1036-1042, 2016.

[16]S. Hiti, D. Boroyevich, and C. Cuadros, "Small-signal modeling and control of three-phase PWM converters," Proceedings 1994 IEEE Industry Applications Society Annual Meeting, 1994, no. 4, pp. 1143-1150.

[17]P. G. Pereirinha and J. P. Trovão, "Multiple Energy Sources Hybridization: The Future of Electric Vehicles?," in New Generation of Electric Vehicles, Zoran Stevic, Intech Open, 2012.

[18]B. Chen, Y. Gao, M. Ehsani, and J. M. Miller, "Design and Control of a Ultracapacitor Boosted Hybrid Fuel Cell Vehicle," in 2009 IEEE Vehicle Power and Propulsion Conference, 2009, pp. 696-703.

[19]"Boeing 737-400 Specs." [Online]. Available: https://www.rocketroute.com/aircraft/boeing-737-400. [Accessed: 06Aug-2019].

[20]O. Grigore-Müler and M. Barbelian, "Regenerative braking for aircraft landing roll phase using an electric machine," 13th Int. Conf. Optim. Electr. Electron. Equip., pp. 584-593, 2012.

[21] J. Sun, J. M. Hoekstra, and J. Ellerbroek, "Aircraft Drag Polar Estimation Based on a Stochastic Hierarchical Model," in SESAR Innovation Days, 2018.

[22]Y. Gao and M. Ehsani, "Parametric Design of the Traction Motor and Energy Storage for Series Hybrid Off-Road and Military Vehicles," IEEE Trans. Power Electron., vol. 21, no. 3, pp. 749-755, 2006.

[23]T. B. Reddy and D. Linden, Linden's handbook of batteries, 4th ed. Mc Graw Hill, 2011.

[24]A. González et al., "Review on supercapacitors: Technologies and materials,” Renew. Sustain. Energy Rev., vol. 58, pp. 1189-1206, 2016.

[25]J. R. Miller and P. Simon, "Electrochemical Capacitors for Energy Management," Science (80-. )., vol. 321, no. 5889, pp. 651-652, 2008.

[26] A. Castaings, W. Lhomme, R. Trigui, and A. Bouscayrol, "Practical control schemes of a battery / supercapacitor system for electric vehicle," IET Electr. Syst. Transp., vol. 6, no. 1, pp. 20-26, 2016.

[27]J. Shen, S. Dusmez, and A. Khaligh, "Optimization of Sizing and Battery Cycle Life in Battery / Ultracapacitor Hybrid Energy Storage Systems for Electric Vehicle Applications," IEEE Trans. Ind. Informatics, vol. 10, no. 4, pp. 2112-2121, 2014.

[28]Maxwell Technologies, "Maxwell Ultracapacitor Cells." [Online]. Available:

http://www.maxwell.com/images/documents/ProductMatrix.pdf. [Accessed: 06-Oct-2019]. 